\title{
BUTTERFLIES AND SKIPPERS OF PLATEAU MOUNTAIN, ALBERTA
}

HAROLD W. PINEL, 1017 - 19 Avenue Northwest, Calgary, Alberta, T2M OZ8 and NORBERT G. KONDLA, Box 762, McBride, British Columbia. VOJ 2E0

Plateau Mountain is located approximately $80 \mathrm{~km}$ southwest of Calgary in the Highwood-Livingston Range of the Rocky Mountains. The top of the mountain is a gently rolling plateau, and it is this feature that gives the mountain its name and makes it stand out from all other mountains in southern Alberta. The summit on the plateau has an elevation of $2,519 \mathrm{~m}$. Timberline generally occurs between 2,135 and 2,300 m, with much local variation due to substrate, topography and wind exposure. $^{7}$

It is due to the accessibility of Plateau Mountain over the years that its butterflies and skippers have been more intensively studied than those of any other mountain in Canada. The Forestry Trunk Road runs along the southern edge of the mountain. On the east side of the mountain there is a major gas well access road in the Upper Livingston River Valley. Side roads leading to well sites provide access to a series of cirques cut into the eastern slopes of the plateau. On the west side of the mountain there is a natural gas well access road that reaches the summit. This gravelled road runs north of the Forestry Trunk Road near the divide between Wilkinson and Dry Creek and winds uphill for about 9.5 $\mathrm{km}$ before reaching the top. This road is closed to public vehicle traffic, but it still provides for easy foot access.

It is believed that the entire pla- teau, rising $2,256 \mathrm{~m}$ at the north end to $2,519 \mathrm{~m}$ at the southern peak, was above the levels of Pleistocene glaciation. Ice may be assumed to have been present in all valleys around the mountain at least at the maximum of the first Cordilleran advance, when it is believed that the general ice level in the mountains of southwestern Alberta rose to about $2,100 \mathrm{~m}^{10}$

There are no glaciers or permanent snowfields on Plateau Mountain, but permafrost exists. Permafrost extends possibly to a depth of $100 \mathrm{~m}$ or more before the plateau, the upper portion (to $30 \mathrm{~m}$ depth) being adjusted to the present climate and the lower levels apparently relic. ${ }^{8}$

Plateau Mountain lies in the rainshadow east of the Continental Divide. Little climatic data has been collected for the area, but Harris and Brown determined the mean annual air temperature to be $-4.1^{\circ} \mathrm{C}$ on the summit, and $0.05^{\circ} \mathrm{C}$ in the subalpine forest at 2,266 m. ${ }^{8}$ These authors give mean precipitation for the plateau from September 1974 to September 1976 as approximately 15 $\mathrm{cm}$. Strong winds occur throughout the year on Plateau Mountain, and are of ecological significance in removing most of the snow from the plateau.

The vegetation of Plateau Mountain and immediately adjacent areas has been studied in detail. ${ }^{7}$ The 


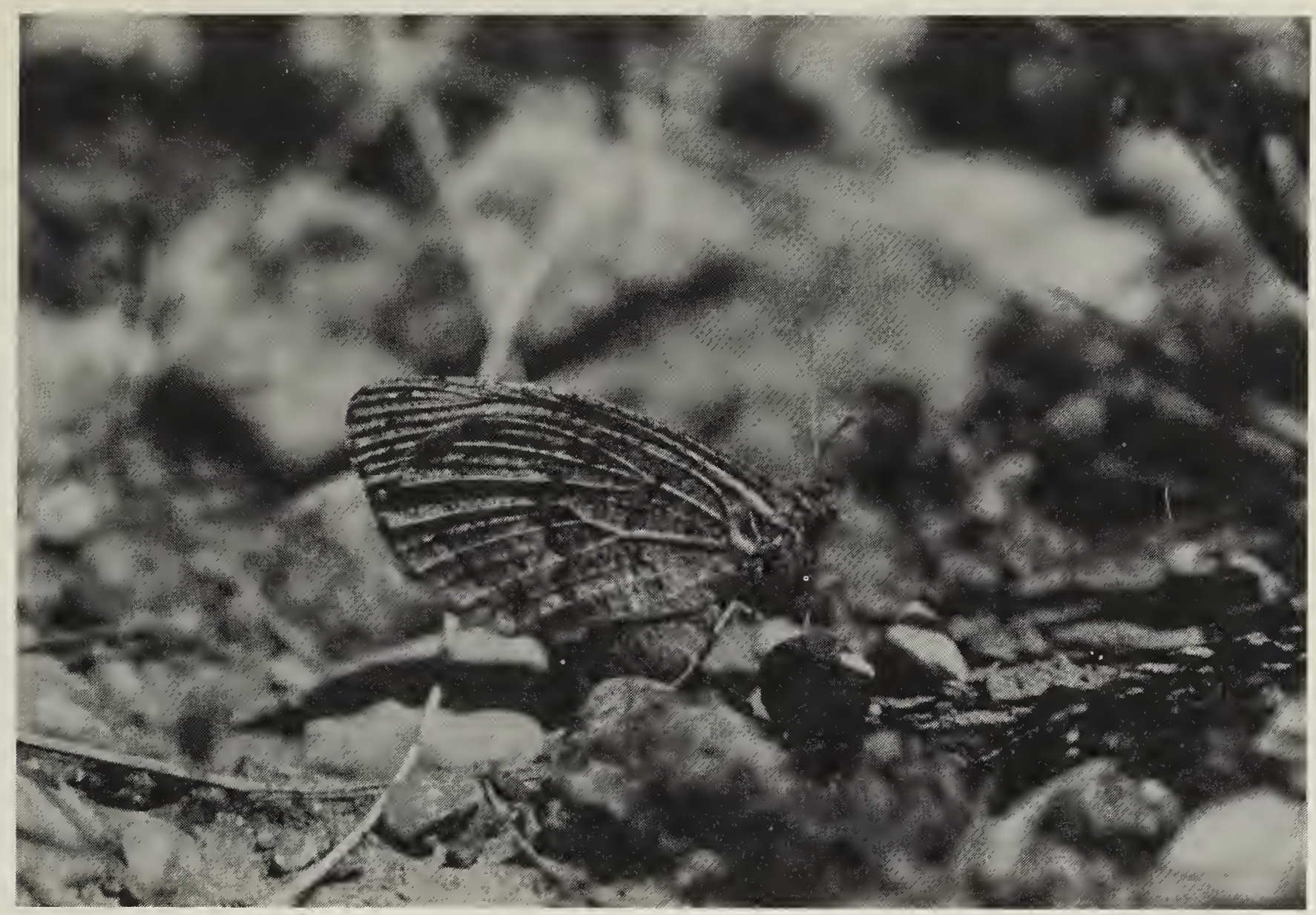

Riding's Satyr

Gary W. Seib

vegetational types vary from barrens and tundra communities to marsh/ meadow and scrub communities to subalpine forest communities to disturbed areas to saxifrage moss community associated with vegetated cliffs where seepage occurs.

The only previous paper on butterflies and skippers for Plateau Mountain was a flight calendar for those specimens known to occur in the alpine zone. ${ }^{2}$ However, the mountain has been frequently visited by lepidopterists and much study material exists in personal and institutional collections, in addition to that used in the preparation of this paper.

Annotated List The following list is a result of field observations and collections made over a period of 29 years from 1962-1990 by the following people: Peter Allen (PA), R.L. Anderson (RA), A. Bird (AB), C.D. Bird (CB), B. and J. Carr (BJC), C.D. Ferris (CF), L.P. Grey (LG), M. Grinnel (MG), Cris Guppy (CG), G.
Hilchie $(\mathrm{GH})$, Norbert Kondla (NK), John Lake (JOL), David Lawrie (DL), J.A. Legge (JL), Ross Lein (RL), A.I.W. MacKenzie (AM), J.S. Nordin (JN), Ted Pike (TP), Harold Pinel (HP), J.D. Reist (JR), Jon Shepard (JS), Steve Shigematsu (SS), Felix Sperling (FS), Ernest Williams (EW), and R.E. Woodley (RW). All the field records occur between 16 June and 12 September. Dates indicating days for which specimen records are available are written in an abbreviated format by day, month, year followed by the collector's initials (e.g., 2/7/87 TP is 2 July 1987 Ted Pike). These are only given for the less common species. For the more common species, the flight period is noted by the first and last dates recorded with specimens.

The frequency and abundance of the different species is subjectively denoted by: common - occurs regularly in good numbers; fairly common - occurs regularly in average numbers; uncommon - occurs regularly 


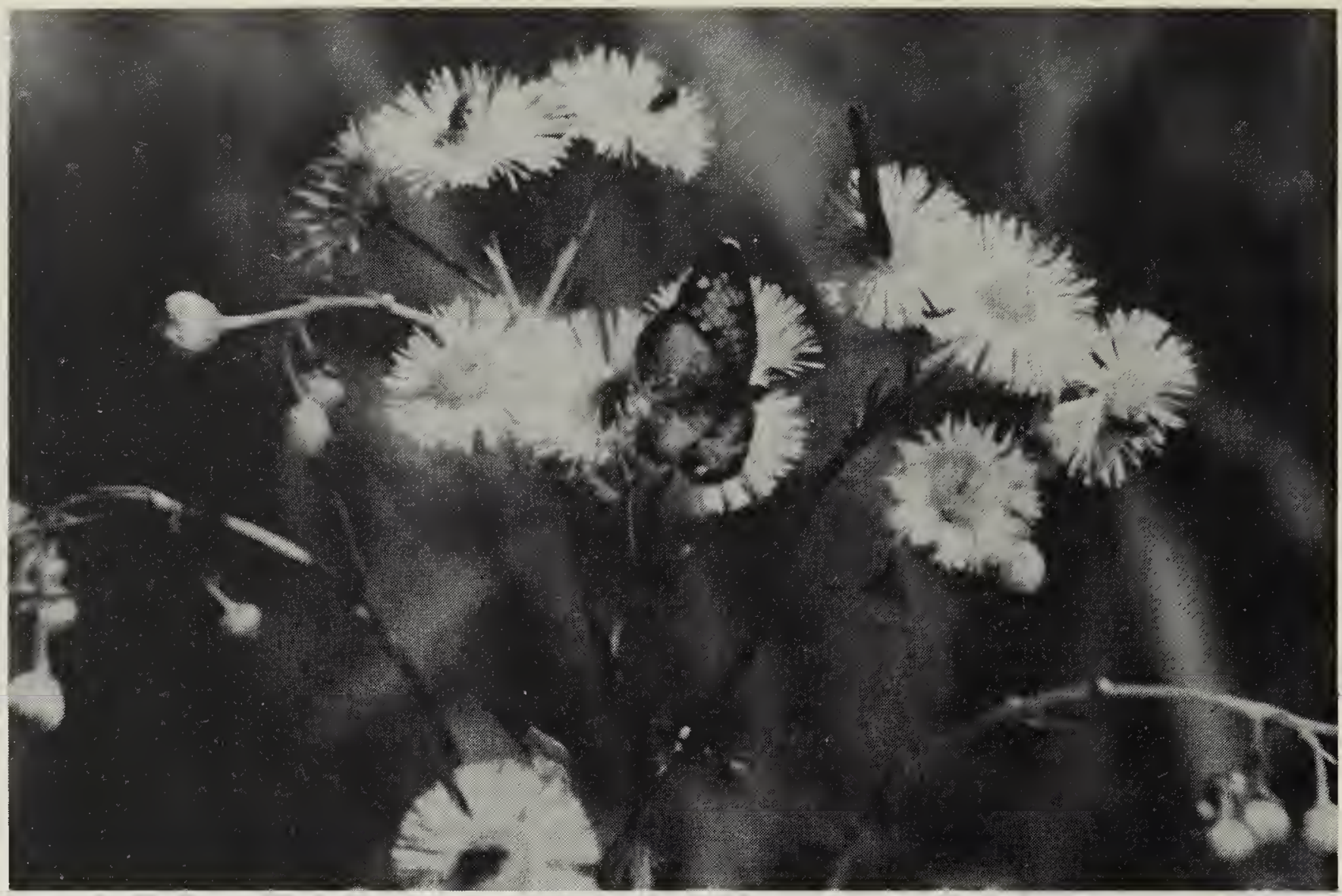

Pearl Crescent

R.W. Knapton

in low numbers; occasional - occurs irregularly; and rare - recorded once or twice and not likely to be seen again.

The common names in the list, with one exception, are from Miller, ${ }^{17}$ while scientific names generally follow Scott. ${ }^{19}$ Deviations are based on more recent research.

\section{Hesperiidae - Skippers}

PERSIUS DUSKY WING (Erynnis persius) - Occasional in open grassy stretches along roadway in subalpine fir-Engelmann spruce forest at low elevations in early July; 10/7/71 TP, 12/7/86 JOL, 2/7/87 TP.

GRIZZLED SKIPPER (Pyrgus centaureae $(0 k I)$ - Uncommon in alpine flight records from 2 July to $6 \mathrm{Au}$ gust. Scott mentions that ssp. loki is biennial, flying mostly in odd years in Colorado, Wyoming and Labrador and at Churchill, Manitoba. ${ }^{19}$ Interestingly, of the ten years for which there are flight records at Plateau
Mountain, this species was recorded only three times in odd years.

ARCTIC SKIPPER (Carterocephalus palaemon) - Rare in open grassy area in subalpine forest; $18 / 7 / 83$ NK, $8 / 7 / 90$ DL. Kondla points out the salient features of the undescribed mountain subspecies. ${ }^{13}$

COMMON BRANDED SKIPPER (Hesperia comma manitoba) - Uncommon in alpine and subalpine meadows in even-numbered years with a recorded flight period of 8 July to 5 August. Field research and analysis of available data by Kondla shows that this taxon flies only in even-numbered years in the Rocky Mountains of Alberta and northern British Columbia. This phenomenon has not been previously reported in the literature.

DRACO SKIPPER (Polites draco) Rare in moist subalpine meadow; 19/7/70 JS, 27/7/80 HP. 


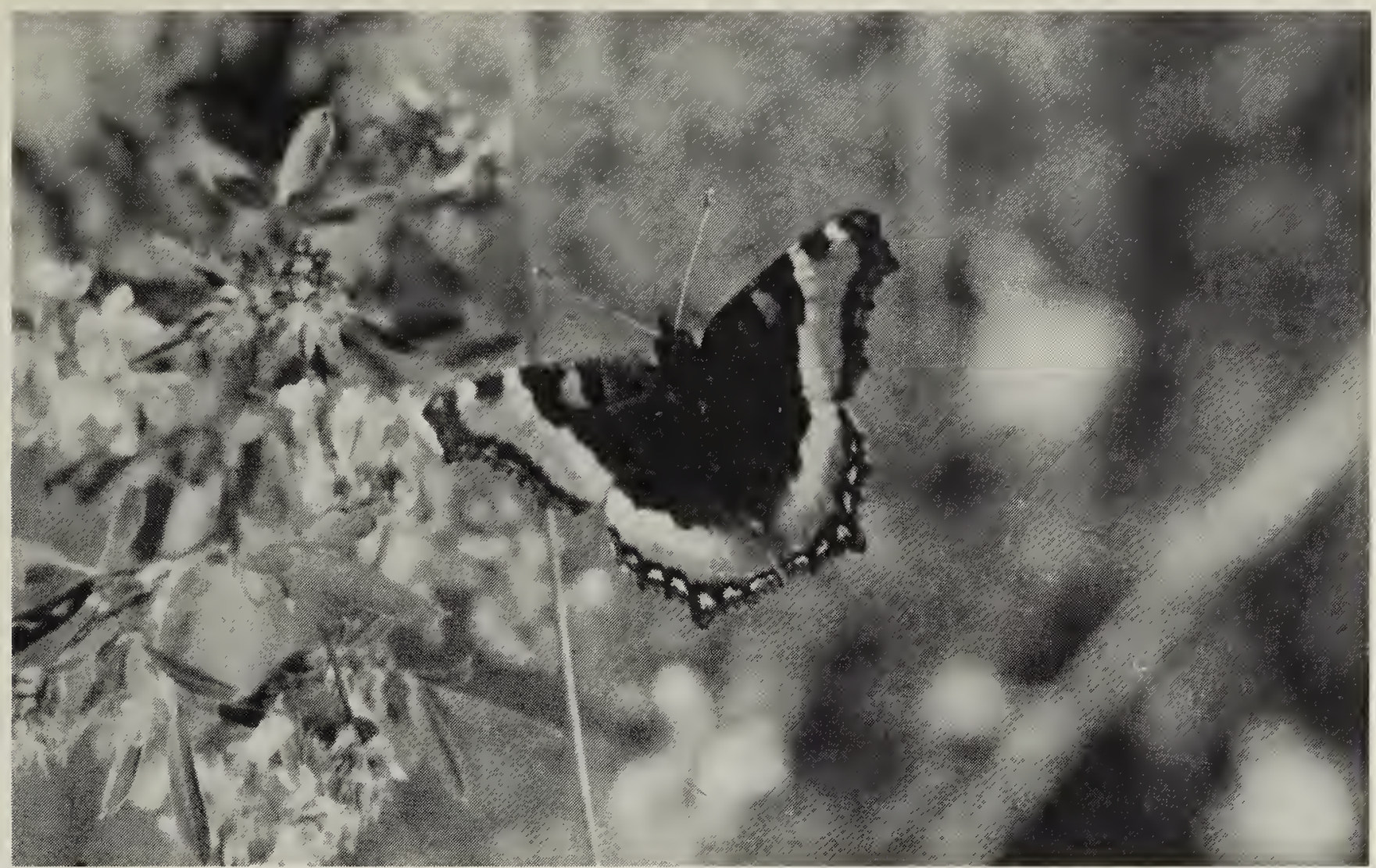

Milbert's Tortoise Shell

Juhachi Asai

\section{Papilionidae - Parnassians and Swallowtails}

PHOEBUS' PARNASSIAN (Parnassius phoebus smintheus) - Common in alpine tundra and subalpine meadows. Flight records from 2 July to 12 September; being most abundant in late July and early August.

ANISE SWALLOWTAIL (Papilio zelicaon) - Rare in open grassy area in subalpine fir-Engelmann spruce woods; 1/8/83 JOL, 29/7/90 DL.

\section{Pieridae - Whites and Sulphurs}

WESTERN WHITE (Pieris occidentalis) - Common in alpine, subalpine meadows and disturbed open areas along roadway in subalpine firEngelmann spruce woods. It is most often seen flying about local prominences. Flight records from 2 July to 7 August.

MARGINED WHITE (Pieris marginalis) - Uncommon and localized, preferring shaded open areas along drainages in subalpine fir-Engel- mann spruce woods. Flight period is from mid-July to early August; 10/7/71 TP, 5/8/72 GH, 16/7/77 HP, 26/7/80 NK, 1/8/83 JOL. Most North American literature has treated Pieris napi species group populations as being subspecies of the European $P$. napi on the basis of superficial morphological similarity. Evidence has been mounting for years that there are distinct species on this continent. Recently, enzyme electrophoretic methods have been used to further the argument that, in North America, there are species that are distinct from $P$. napi. ${ }^{6}$ In Alberta, there are two species - $P$. oleracea which occurs in the boreal forest and $P$. marginalis which occurs in the mountains.

CABBAGE BUTTERFLY (Pieris rapae) - Occasional in disturbed area along roadways in July: 26/7/78 NK, 19/7/83 NK, 22/7/83 HP.

LARGE MARBLE (Euchloe ausonides) - Occasional in open grassy area along roadway in subalpine fir-Engelmann spruce woods 
from early July to early August; 5/8/72 GH, 2/7/87 TP, 8/7/88 HP.

NORTHERN MARBLE (Euchloe creusa) - Uncommon in subalpine meadows and alpine tundra with flight records from 24 June to 6 August.

SARA ORANGE TIP (Anthocharis sara) - Occasional in clearings in subalpine fir-Engelmann spruce woods in July; 16/7/77 HP, 22/7/83 HP. We use the species epithet "sara" only as a convenient handle to refer to the Anthocharis sara complex. Geiger and Shapiro present compelling evidence that present taxonomy in the gross morphospecies "sara" is unsatisfactory.

CLOUDED SULPHUR (Colias philodice eriphyle) - Common in alpine and open areas in subalpine forest with a recorded flight period of 2 July to 11 August.

ALFALFA BUTTERFLY (Colias eurytheme) - Rare in alpine; 12/7/86 JOL.

CHRISTINA SULPHUR (Colias christina astraea) - Uncommon in subalpine meadows and clearings in subalpine forest. Flight period recorded from 2 July to 7 August. Recent studies show that the taxa christina and astraea are not conspecific with $C$. alexandra as treated in the literature for the past 30 years. $^{4,15}$

MEAD'S SULPHUR (Colias meadii elis) - Common in alpine tundra and subalpine meadows. Flight records from 2 July to 12 September.

\section{LABRADOR SULPHUR (Colias} nastes streckeri) - Common in alpine tundra with flight records from 2 July to 22 August.
PELIDNE SULPHUR (Colias pelidne skinneri) - Occasional in alpine and clearings in subalpine woods: $31 / 7 / 69$ JS, 5/8/72 GH, 7/8/77 SS.

\section{Lycaenidae - Gossamer Wings}

LITTLE COPPER (Lycaena phlaeas arethusa) - Common in alpine and subalpine meadows with flight periods from 2 July to 12 September, being most abundant in late July and early August.

LUSTROUS COPPER (Lycaena cuprea snowi) - Fairly common, but local, in alpine area. Flight records from 2 July to 7 August.

WESTERN TAILED BLUE (Everes amyntula albrighti) - Rare in open area in lower elevation subalpine forest: 3/7/71 TP.

SILVERY BLUE (Glaucopsyche lygdamus couperi) - Occasional in clearings in subalpine woods; 26/7/69 JS, 18/7/81 NK, 22/7/83 HP, $8 / 7 / 90$ DL. Substantial species-level differences between the taxa lydamus and couperi have been documented. ${ }^{3}$ The butterfly which occurs in Alberta may well become widely known as Glaucopsyche couperi.

NORTHERN BLUE (Lycaeides idas) - Fairly common in subalpine meadows and alpine tundra with flight records from 2 July to $7 \mathrm{Au}$ gust. The most appropriate subspecies name for southwestern Alberta material is not clear at the time of writing. The name atrapraetextus may be more appropriate than scudderi which has traditionally been attributed to the Alberta fauna.

MELISSA BLUE (Lycaeides melissa) - Rare in alpine areas and grassy cirques; $3 / 7 / 71$ TP, 20/8/73 GH, 
26/7/80 NK. This species is principally a grassland species in Alberta with small populations fingering their ways west into the foothills and mountains of southern Alberta.

GREENISH BLUE (Plebejus saepiolus amica) - Fairly common in moist alpine tundra, subalpine meadows and moist clearings in subalpine forest. Flight records from 2 July to 12 September.

ICARIOIDES BLUE (Plebejus icarioides pembina) - Occasional in alpine and subalpine as a stray from mid-July to early August; 5/8/72 GH and TP, 22/8/72 FS, 20/7/73 GH, $4 / 8 / 74 \mathrm{GH}, 22 / 7 / 83 \mathrm{HP}$. The larval food plant, Lupinus spp., is not found in the study area, but occurs at lower elevations nearby.

RUSTIC BLUE (Plebejus rusticus megalo) - Common in alpine tundra and subalpine meadows with flight records from 2 July to 8 September.

\section{Nymphalidae - Brushfoots}

VARIEGATED FRITILLARY (Euptoieta claudia) - Occasional in alpine; 20/7/72 TP, 19/7/86 GH, 23/7/90 DL.

EDWARD'S FRITILLARY (Speyeria edwardsii) - rare in alpine; 4/8/74 PA.

ZERENE FRITILLARY (Speyeria zerene garretti) - Uncommon in subalpine meadows and alpine tundra. Flight records from 2 July to 5 August.

CALLIPPE FRITILLARY (Speyeria callippe calgariana) - Rare in alpine; 19/7/70 JS, 26/7/80 HP.

NORTHWESTERN FRITILLARY (Speyeria electa) - Occasional in alpine tundra, subalpine meadows, and clearings in subalpine woods with flight records from 2 July to 5 August. For the reasons given in Kondla, the authors side with Howe and Klassen et al. in recognizing this taxon as a separate species from Speyeria atlantis. $9,11,14$

MORMON FRITILLARY (Speyeria mormonia) - Fairly common in alpine tundra, subalpine meadows, and open areas in subalpine woods. Flight period from 2 July to 12 September.

BOG FRITILLARY (Boloria eunomia) - Common in moist subalpine and alpine areas dominated by willows. Flight period from 2 July to $23 \mathrm{Au}$ gust.

SILVER-BORDERED FRITILLARY (Boloria selene) - Rare: a stray was collected in the alpine on $22 / 7 / 83$ NK.

FREIJA FRITILLARY (Boloria freija) - Rare in dry open areas in subalpine fir-Engelmann spruce woods: 24/6/77 NK.

ALBERTA FRITILLARY (Boloria a/berta) - Uncommon and local in odd-numbered years in alpine tundra with flight records from 2 July to 19 September. In Alberta, this species is known from only two locations south of Banff National Park. Real abundance of this species is unknown due to its biennial flight habits and propensity to fly over steep fellfields which are hazardous to naturalists.

ASTARTE FRITILLARY (Boloria astarte) - Fairly common but local in alpine tundra, generally found flying rocky ridges close to its food plant, Saxifraga bronchialis. Flight records from 2 July to 11 August. 
TITANIA FRITILLARY (Boloria titania grandis) - Fairly common in clearings in subalpine woods and in subalpine meadows, with a recorded flight period of 2 July to 18 August.

\section{NORTHERN CHECKERSPOT (Chlosyne palla) - Rare in moist subalpine meadows; 5/8/72 GH.}

\section{DAMOETUS CHECKERSPOT} (Chlosyne damoetus) - Occasional in the alpine with flight records from 20 July to 8 August.

\section{PEARL CRESCENT (Phyciodes} morpheus) - Rare in clearings in subalpine woods at lower elevations; 19/7/83 NK, 22/7/83 HP.

\section{FIELD CRESCENT (Phyciodes} pratensis) - Uncommon in subalpine meadows, clearings in subalpine woods, and alpine tundra from 2 July to 5 August.

ANICIA CHECKERSPOT (Euphydryas anicia) - Common in alpine tundra, subalpine meadows, and clearings and roadways in subalpine woods. Flight period from 2 July to 6 August.

EDITH'S CHECKERSPOT (Euphydryas editha) - Common, but fairly local, in alpine tundra with a recorded flight period of 2 July to 11 August.

\section{SATYR ANGLEWING (Polygonia} satyrus) - Rare along streams in subalpine woods; $7 / 8 / 77$ SS, $27 / 7 / 80$ TP, 31/7/83 NK.

\section{ZEPHYR (Polygonia zephyrus) -} Rare in alpine; $6 / 8 / 89 \mathrm{HP}$. This is a woodland species, but summer adults often fly to the higher elevations of mountains, even to the alpine zone to feed on flowers. ${ }^{19}$
CALIFORNIA TORTOISE SHELL (Nymphalis californica) - Rare migrant in alpine tundra where it was recorded in July of 1987; three individuals on 2/7/87 TP; two on 12/7/87 NK; and singles on 14/7/87 MG and 15/7/87 MG.

\section{MILBERT'S TORTOISE SHELL} (Nymphalis milberti furcillata) Common in alpine tundra, subalpine meadows, and clearings and roadways in subalpine woods. Flight records from 12 July to 11 August.

PAINTED LADY (Vanessa cardui) Occasional migrant species observed in all habitats; $5 / 8 / 72 \mathrm{GH}$, 29/7/73 SS, 19/7/83 NK, 22/7/83 HP.

WHITE ADMIRAL (Limenitis arthemis rubrofasciata) - Rare in moist subalpine meadows and moist clearings in subalpine woods; 21/7/75 SS, 25/7/83 EW, 1/8/83 JOL.

\section{Satyridae - Satyrs, Browns, and Wood Nymphs}

RINGLET (Coenonympha tullia benjamini) - Occasional in alpine tundra, subalpine meadows, and along roadway clearings in subalpine forest during July and the first half of $\mathrm{Au}$ gust; 11/8/63 AM, 21/7/74 GH, 27/7/80 TP, 31/7/83 NK, 9/7/88 HP, 6/8/89 HP.

COMMON ALPINE (Erebia epipsodea epipsodea) - Common in alpine tundra, subalpine meadows, and in roadway clearings in subalpine woods. Flight records from 2 July to 7 August.

RIDINGS' SATYR (Neominois ridingsii minimus) - Rare straggler collected in alpine tundra 18/7/79 CG. This record is the only known high elevation mountain record for the province. The normal range of this 


\begin{tabular}{|c|c|c|c|c|c|c|}
\hline \multirow[t]{2}{*}{ Table 1.} & \multicolumn{6}{|c|}{$\begin{array}{l}\text { COMPARISON OF PLATEAU MOUNTAIN RHOPALOCERAN FAUNA } \\
\text { TO THE FAUNA OF PETER LOUGHEED PROVINCIAL PARK AND } \\
\text { THE TOTAL PROVINCIAL FAUNA }\end{array}$} \\
\hline & \multicolumn{2}{|c|}{ Plateau Mountain } & \multicolumn{2}{|c|}{ Alberta } & \multicolumn{2}{|c|}{$\begin{array}{l}\text { Peter Lougheed } \\
\text { Provincial Park }\end{array}$} \\
\hline Family & $\begin{array}{c}\text { No. of } \\
\text { species }\end{array}$ & $\begin{array}{c}\% \\
\text { of fauna }\end{array}$ & $\begin{array}{c}\text { No. of } \\
\text { species }\end{array}$ & $\begin{array}{c}\% \\
\text { of fauna }\end{array}$ & $\begin{array}{c}\text { No. of } \\
\text { species }\end{array}$ & $\begin{array}{c}\% \\
\text { of fauna }\end{array}$ \\
\hline Hesperiidae & 5 & 8.5 & 27 & 16.7 & 5 & 8.5 \\
\hline Papilionidae & 2 & 3.4 & 7 & 4.3 & 2 & 3.4 \\
\hline Pieridae & 12 & 20.3 & 23 & 14.2 & 13 & 22.0 \\
\hline Lycaenidae & 9 & 15.2 & 35 & 21.6 & 9 & 15.2 \\
\hline Nymphalidae & 24 & 40.7 & 51 & 31.5 & 23 & 39.0 \\
\hline Danaidae & 0 & 0 & 1 & 0.6 & 0 & 0 \\
\hline Satyridae & 7 & 11.9 & 18 & 11.1 & 7 & 11.9 \\
\hline & 59 & 100 & 162 & 100 & 59 & 100 \\
\hline
\end{tabular}

species is the mixed grasslands of southeastern Alberta. Subspecies minimus was described by Austin. ${ }^{1}$

CHRYXUS ARCTIC (Oeneis chryxus chryxus) - Common in alpine tundra, subalpine meadows, and clearings in subalpine woods with flight records from 2 July to 7 August.

\section{UHLER'S ARCTIC (Oeneis uhleri} varuna) - Occasional in alpine tundra; 16/6/74 GH, 17/7/79 CG, 26/7/84 JS, 6/8/89 HP.

JUTTA ARCTIC (Oeneis jutta chermockl) - Rare in moist boggy area in subalpine forest; 4 \& 5/8/78 NK, 11/7/87 NK.

MELISSA ARCTIC (Oeneis melissa beani) - Fairly common in alpine tundra with flight records from 9 July to 6 August.

Discussion The known butterfly and skipper fauna of Plateau Mountain consist of 59 species, representing 6 of the 7 families of Rhopalocerans found in Alberta as follows: Hesperiidae -5 , Papilionidae -2 , Pieridae - 12, Lycaenidae - 9, Nymphalidae -24 , and Satyridae -7 . Table 1 compares the Rhopaloceran fauna of the study area to that of Alberta. As shown in Table 1, the Plateau Mountain fauna has a significantly greater portion of its fauna represented by the Pieridae and Nymphalidae, and a significantly lesser portion presented by the Hesperiidae and Lycaenidae, than the total Alberta fauna.

It is noteworthy that the same number of butterfly and skipper species have been recorded at Plateau Mountain as in the entire Peter Lougheed (Kananaskis) Provincial Park, a park of 50,308 ha whose southern boundary is approximately $50 \mathrm{~km}$ north of Plateau Mountain. ${ }^{16}$ As well, an almost identical number of species per family has been recorded in both areas as illustrated in Table 1. In comparing the actual species, $76 \%$ (45 of 59 ) are common to both Plateau Mountain and Peter Lougheed Provincial Park.

Of the 59 species recorded for Plateau Mountain, 55 (93.2\%) have been reported in July and 44 (74.6\%) have been reported in August. Table 2 summarizes the known temporal distribution for each butterfly and skipper species recorded for Plateau Mountain. Figures 1 and 2 graph the 


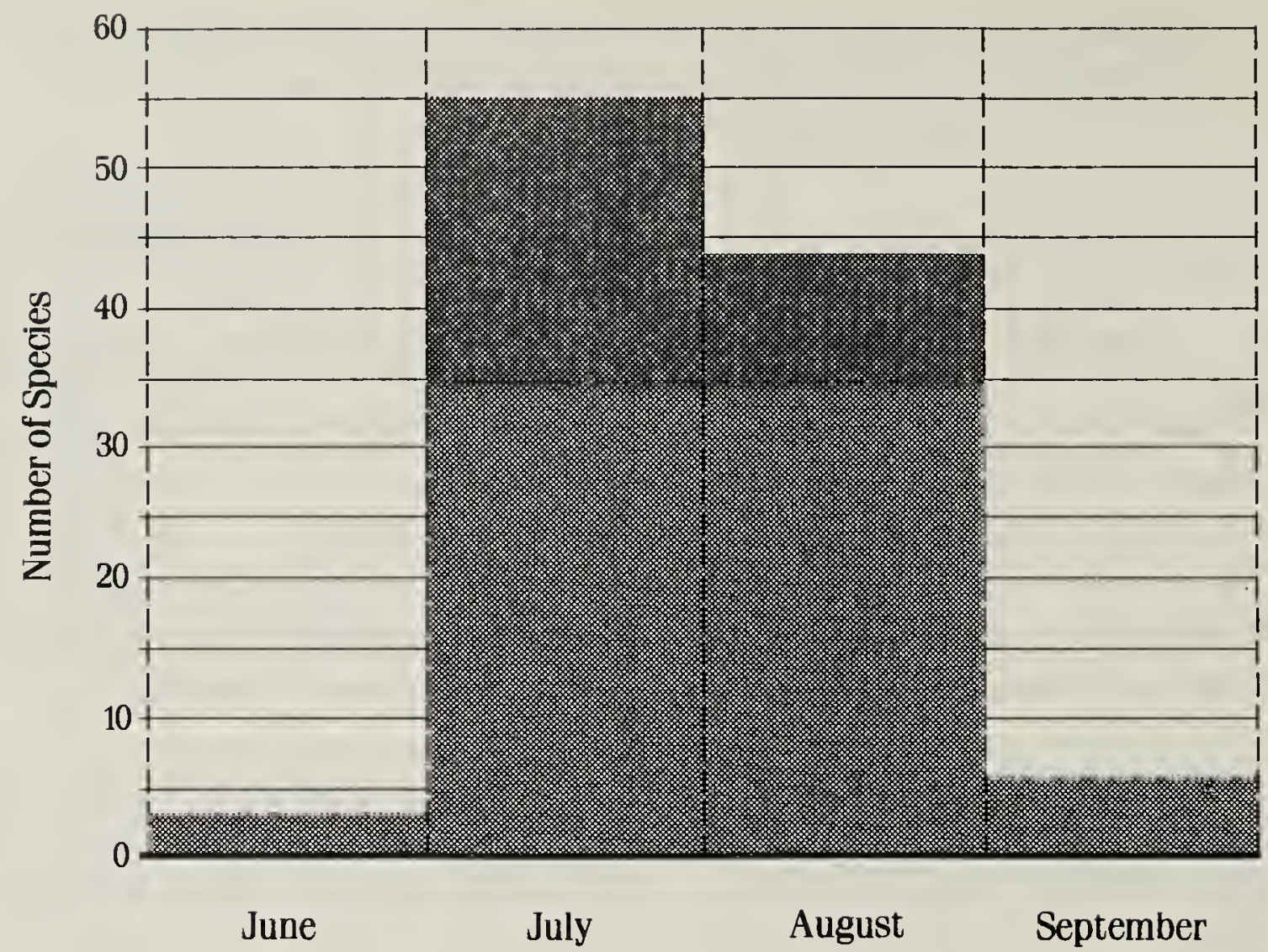

Figure 1. NUMBER OF BUTTERFLY AND SKIPPER SPECIES RECORDED ON A MONTHLY BASIS.

species diversity on a monthly and weekly basis. The greatest diversity of species occurs during the last half of July and the first week of August. The temporal data also illustrate that a large diversity of species is recorded over a short time span. This is further amplified when one realizes that all the field data throughout the years 1962 and 1990 fall within the time period of 16 June to 12 September, a period of just under 90 days.

A unique assemblage of butterfly species has been recorded for Plateau Mountain. There are migrants and strays represented by species such as Colias eurytheme, Euptoieta claudia, Nymphalis californica, Vanessa cardui, and Neominois ridingsii minimus. The first four species are expected, but the record of Riding's Satyr is extremely unusual. The Riding's Satyr is a characteristic butterfly of dry mixed grasslands in southeastern Alberta, with few records west of a line drawn from Fort MacLeod in the south to Drumheller in the north. The report from Plateau
Mountain is the only mountain record for the province, and represents one of the late dates for this species' known flight period (11 June -23 July) in Alberta.

A number of other species recorded on Plateau Mountain occur there irregularly, and in the annotated list they are described as rare or occasional. These are species for which little or no suitable habitat and/or food plants exist in the study area, but suitable habitat exists nearby, mainly to the east in the foothills where mixed woods, aspen woods, and pockets of grasslands, and wetland complexes exist. $^{18}$ Species in this category include Erynnis persius, Carterocephalus palaemon, Papilio zelicaon, Everes amyntula albrighti, Speyeria edwardsii, Boloria selene, Boloria freija, Chlosyne palla, Phyciodes morpheus, and Polygonia zephyrus. Pinel recorded all these species except $C$. palaemon and $P$. zephyrus in a small study area around Indian Grave Campground, an area approximately only $9 \mathrm{~km}$ east of Plateau Mountain, and suitable 


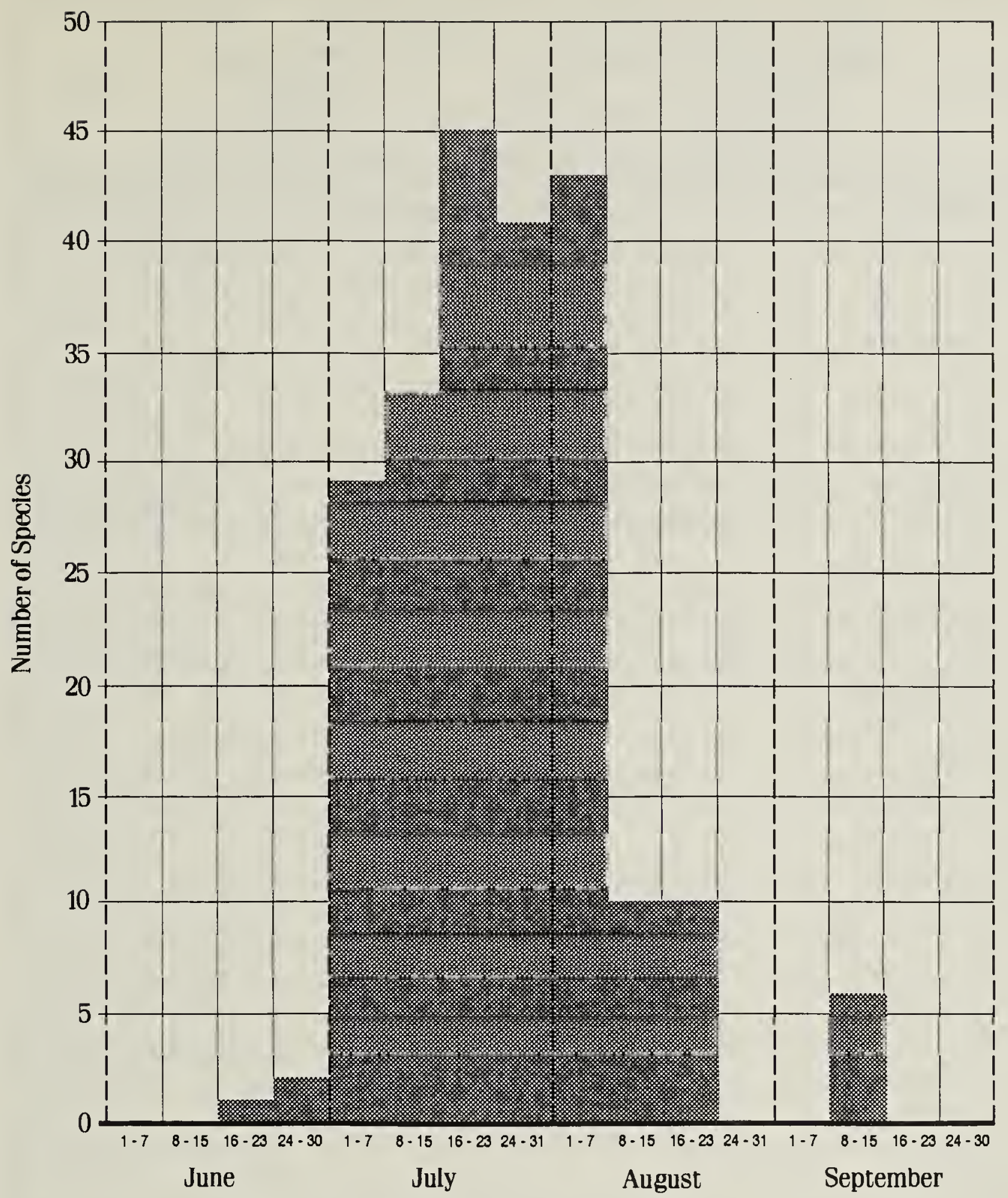

Figure 2. NUMBER OF BUTTERFLY AND SKIPPER SPECIES RECORDED ON A WEEKLY BASIS.

habitat exists even closer to Plateau Mountain for all these species. ${ }^{18}$

Why have so many lower elevation species of various habitats turned up in the alpine and upper subalpine zones of Plateau Mountain? One reason is hilltopping as a result of mate-locating behaviour. ${ }^{12}$ Another factor that comes into play in mountainous areas is the well known phenomenon of upslope winds due to daytime warming of the land. These upslope mountain winds assist spe- cies that are moving up slopes for purposes of mate location, but also transport other species which do not engage in mate-locating hilltopping behaviour to mountain tops.

In examining the data, two species were noted to have biennial flight periods on Plateau Mountain. Boloria alberta occurs only in odd-numbered years, while Hesperia comma manitoba flies only in even-numbered years. Another interesting observation was the large number of 
Table 2. TEMPORAL DISTRIBUTION OF BUTTERFLIES

AND SKIPPERS RECORDED AT PLATEAU MOUNTAIN

\begin{tabular}{|c|c|c|c|c|c|c|c|c|c|c|c|c|}
\hline & \multicolumn{2}{|c|}{ June } & \multicolumn{4}{|c|}{ July } & \multicolumn{4}{|c|}{ August } & \multicolumn{2}{|c|}{ Sept. } \\
\hline & $\begin{array}{l}16- \\
23\end{array}$ & $\begin{array}{l}24- \\
30 \\
\end{array}$ & $1-7$ & $\begin{array}{l}8- \\
15 \\
\end{array}$ & $\begin{array}{l}16- \\
23 \\
\end{array}$ & $\begin{array}{l}24- \\
31 \\
\end{array}$ & $1-7$ & $\begin{array}{l}8- \\
15 \\
\end{array}$ & $\begin{array}{l}16- \\
23 \\
\end{array}$ & $\begin{array}{l}24- \\
31 \\
\end{array}$ & $1-7$ & $\begin{array}{l}8- \\
15 \\
\end{array}$ \\
\hline HESPERIIDAE & & & & & & & & & & & & \\
\hline Erynnis persius & & & $x$ & $x$ & & & & & & & & \\
\hline $\begin{array}{l}\text { Pyrgus } \\
\text { centaureae loki }\end{array}$ & & & $x$ & $x$ & $x$ & $x$ & $x$ & & & & & \\
\hline $\begin{array}{l}\text { Carterocephalus } \\
\text { palaemon }\end{array}$ & & & & $x$ & $x$ & & & & & & & \\
\hline $\begin{array}{l}\text { Hesperia comma } \\
\text { manitoba }\end{array}$ & & & & $x$ & $x$ & $x$ & $x$ & & & & & \\
\hline Polites draco & & & & & $x$ & $x$ & & & & & & \\
\hline PAPILIONIDAE & & & & & & & & & & & & \\
\hline $\begin{array}{l}\text { Parnassius } \\
\text { phoebus smintheus }\end{array}$ & & & $x$ & $x$ & $x$ & $x$ & $x$ & $x$ & $x$ & & & $x$ \\
\hline Papilio zelicaon & & & & & & $x$ & $x$ & & & & & \\
\hline PIERIDAE & & & & & & & & & & & & \\
\hline Pieris occidentalis & & & $x$ & $x$ & $x$ & $x$ & $x$ & & & & & \\
\hline Pieris marginalis & & & & $x$ & $x$ & $x$ & $x$ & & & & & \\
\hline Pieris rapae & & & & & $x$ & $x$ & & & & & & \\
\hline Euchloe ausonides & & & $x$ & $x$ & & & $x$ & & & & & \\
\hline Euchloe creusa & & $x$ & & $x$ & $x$ & $x$ & $x$ & & & & & \\
\hline Anthocharis sara & & & & & $x$ & & & & & & & \\
\hline $\begin{array}{l}\text { Colias philodice } \\
\text { eriphyle }\end{array}$ & & & $x$ & $x$ & $x$ & $x$ & $x$ & $x$ & & & & \\
\hline Colias eurytheme & & & & $x$ & & & & & & & & \\
\hline $\begin{array}{l}\text { Colias christina } \\
\text { astraea }\end{array}$ & & & $x$ & & $x$ & & $x$ & & & & & \\
\hline Colias meadii elis & & & $x$ & $x$ & $x$ & $x$ & $x$ & & $x$ & & & $\underline{x}$ \\
\hline $\begin{array}{l}\text { Colias nastes } \\
\text { streckeri }\end{array}$ & & & $x$ & $x$ & $x$ & $x$ & $x$ & $x$ & $x$ & & & \\
\hline $\begin{array}{l}\text { Colias pelidne } \\
\text { skinneri }\end{array}$ & & & & & & $x$ & $x$ & & & & & \\
\hline LYCAENIDAE & & & & & & & & & & & & \\
\hline $\begin{array}{l}\text { Lycaena phlaeas } \\
\text { arethusa }\end{array}$ & & & $x$ & $x$ & $x$ & $x$ & $x$ & $x$ & $x$ & & & $x$ \\
\hline $\begin{array}{l}\text { Lycaena cuprea } \\
\text { snowi }\end{array}$ & & & $x$ & $x$ & $x$ & $x$ & $x$ & & & & & \\
\hline $\begin{array}{l}\text { Everes amyntula } \\
\text { albrighti }\end{array}$ & & & $x$ & & & & & & & & & \\
\hline $\begin{array}{l}\text { Glaucopsyche } \\
\text { lygdamus couperi }\end{array}$ & & & & $x$ & $x$ & $x$ & & & & & & \\
\hline Lycaeides idas & & & $x$ & & $x$ & $x$ & $x$ & & & & & \\
\hline Lycaeides melissa & & & $x$ & & & $x$ & & & $x$ & & & \\
\hline $\begin{array}{l}\text { Plebejus } \\
\text { saepiolus amica }\end{array}$ & & & $x$ & $x$ & $x$ & $x$ & $x$ & & & & & $x$ \\
\hline $\begin{array}{l}\text { Plebejus icarioides } \\
\text { pembina }\end{array}$ & & & & & $x$ & & $x$ & & $x$ & & & \\
\hline $\begin{array}{l}\text { Plebejus rusticus } \\
\text { megalo }\end{array}$ & & & $x$ & $x$ & $x$ & $x$ & $x$ & $x$ & $x$ & & & $x$ \\
\hline
\end{tabular}




\section{Table 2. Continued}

\begin{tabular}{|c|c|c|c|c|c|c|c|c|c|c|c|c|}
\hline & \multicolumn{2}{|c|}{ June } & \multicolumn{4}{|c|}{ July } & \multicolumn{4}{|c|}{ August } & \multicolumn{2}{|c|}{ Sept. } \\
\hline & $\begin{array}{l}16- \\
23\end{array}$ & $\begin{array}{l}24- \\
30\end{array}$ & $1-7$ & $\begin{array}{l}8- \\
15\end{array}$ & $\begin{array}{l}16- \\
23\end{array}$ & $\begin{array}{l}24- \\
31\end{array}$ & $1-7$ & $\begin{array}{l}8- \\
15\end{array}$ & $\begin{array}{l}16- \\
23\end{array}$ & $\begin{array}{l}24- \\
31\end{array}$ & $1-7$ & $\begin{array}{l}8- \\
15 \\
\end{array}$ \\
\hline \multicolumn{13}{|l|}{ NYMPHALIDAE } \\
\hline Euptoieta claudia & & & & & $x$ & & & & & & & \\
\hline Speyeria edwardsii & & & & & & & $x$ & & & & & \\
\hline $\begin{array}{l}\text { Speyeria zerene } \\
\text { garretti }\end{array}$ & & & $x$ & & $x$ & $x$ & $x$ & & & & & \\
\hline $\begin{array}{l}\text { Speyeria callippe } \\
\text { calgariana }\end{array}$ & & & & & $x$ & $x$ & & & & & & \\
\hline Speyeria electa & & & $x$ & & $x$ & $x$ & $x$ & & & & & \\
\hline Speyeria mormonia & & & $x$ & $x$ & $x$ & $x$ & $x$ & $x$ & $x$ & & & $x$ \\
\hline Boloria eunomia & & & $x$ & $x$ & $x$ & $x$ & $x$ & & $x$ & & & \\
\hline Boloria selene & & & & & $x$ & & & & & & & \\
\hline Boloria freija & & $x$ & & & & & & & & & & \\
\hline Boloria alberta & & & $x$ & $x$ & $x$ & $x$ & $x$ & & & & & \\
\hline Boloria astarte & & & $x$ & $x$ & $x$ & $x$ & $x$ & $x$ & & & & \\
\hline $\begin{array}{l}\text { Boloria titania } \\
\text { grandis }\end{array}$ & & & $x$ & $x$ & $x$ & $x$ & $x$ & & $x$ & & & \\
\hline Chlosyne palla & & & & & & & $x$ & & & & & \\
\hline Chlosyne damoetus & & & & & $x$ & $x$ & $x$ & & & & & \\
\hline $\begin{array}{l}\text { Phyciodes } \\
\text { morpheus }\end{array}$ & & & & & $x$ & & & & & & & \\
\hline Phyciodes pratensis & & & $x$ & $x$ & $x$ & $x$ & $x$ & & & & & \\
\hline Euphydryas anicia & & & $x$ & $x$ & $x$ & $x$ & $x$ & & & & & \\
\hline Euphydryas editha & & & $x$ & $x$ & $x$ & $x$ & $x$ & $x$ & & & & \\
\hline Polygonia satyrus & & & & & & $x$ & $x$ & & & & & \\
\hline Polygonia zephyrus & & & & & & & $x$ & & & & & \\
\hline $\begin{array}{l}\text { Nymphalis } \\
\text { californica }\end{array}$ & & & $x$ & $x$ & & & & & & & & \\
\hline $\begin{array}{l}\text { Nymphalis milberti } \\
\text { furcillata }\end{array}$ & & & & $x$ & $x$ & $x$ & $x$ & $x$ & & & & \\
\hline Vanessa cardui & & & & & $x$ & $x$ & $x$ & & & & & \\
\hline $\begin{array}{l}\text { Limenitis arthemis } \\
\text { rubrofasciata }\end{array}$ & & & & & $x$ & $x$ & $x$ & & & & & \\
\hline \multicolumn{13}{|l|}{ SATYRIDAE } \\
\hline $\begin{array}{l}\text { Coenonympha tullia } \\
\text { benjamini }\end{array}$ & & & $x$ & $x$ & $x$ & $x$ & $x$ & $x$ & & & & \\
\hline Erebia epipsodea & & & $x$ & $x$ & $x$ & $x$ & $x$ & & & & & \\
\hline $\begin{array}{l}\text { Neominois ridingsii } \\
\text { minimus }\end{array}$ & & & & & $x$ & & & & & & & \\
\hline $\begin{array}{l}\text { Oeneis chryxus } \\
\text { chryxus }\end{array}$ & & & $x$ & $x$ & $x$ & $x$ & $x$ & & & & & \\
\hline $\begin{array}{l}\text { Oeneis uhleri } \\
\text { varuna }\end{array}$ & $x$ & & & & $x$ & $x$ & $x$ & & & & & \\
\hline $\begin{array}{l}\text { Oeneis jutta } \\
\text { chermocki }\end{array}$ & & & & $x$ & & & $x$ & & & & & \\
\hline $\begin{array}{l}\text { Oeneis melissa } \\
\text { beani }\end{array}$ & & & & $x$ & $x$ & $x$ & $x$ & & & & & \\
\hline
\end{tabular}


Milbert's Tortoise Shell (Nymphalis milberti furcillata) seen flying and nectaring in the alpine zone during the summer. This species is commonly associated with disturbed areas and clearings at lower elevations where its food plant Common Nettle (Urtica gracilis) grows.

Some of the species recorded for the alpine area of Plateau Mountain such as Lycaena cuprea snowi, Chlosyne damoetus, Euphydryas editha, Boloria alberta, Boloria astarte, and Oeneis melissa beani are largely restricted to alpine areas in Alberta.

In 1991, the Government of Alberta and Husky Oil joined forces to establish Plateau Mountain as an ecological reserve. The protection now afforded this unique area will help preserve its butterfly fauna. As well, a number of other representative and special natural features will be protected for future generations to enjoy.

Acknowledgements The authors thank the people listed in the preamble to the annotated list for sharing their information about the butterflies of Plateau Mountain. The paper would not have been possible without their contributions. Information provided by Gerry Hilchie and Ted Pike has been especially helpful in rounding out our knowledge of the Plateau Mountain fauna.

1. AUSTIN, G.T. 1986. A review of the Satyrine genus Neominois, with descriptions of three new subspecies. Bul. of the Allyn Mus. 107:1-27.

2. BIRD, C.D. 1975. A calendar of the butterflies and skippers of the alpine area of Plateau Mountain. Alta. Nat. 5(1):26-28.

3. DIRIG, R. and J.F. CRYAN. 1991. The status of Silvery Blue subspecies
(Glaucopsyche lygdamus and G. I. couperi: Lycaenidae) in New York. J. of the Lepidopterists' Society 45:27290.

4. FERRIS, C.D. 1993. Reassessment of the Colias alexandra group, the legume-feeding species, and preliminary cladistic analysis of the North American Colias (Pieridae: Coliadinae). Bull. of the Allyn Mus. No. 138. $91 \mathrm{pp}$.

5. GEIGER, H. and A.M. SHAPIRO. 1986. Electrophoretic evidence for speciation within the nominal species Anthocharis sara Lucas (Pieridae). J. of Research on the Lepidoptera 25:15-24.

6. 1992. Genetics, systematics and evolution of holarctic Pieris napi species group populations (Lepidoptera, Pieridae). Z. zool. Syst. Evolut. forsch. 30:100-22.

7. GRIFFITHS, G.C.D. 1982. Vegetation survey and mapping of the Plateau Mountain candidate ecological reserve. Alberta Energy and Natural Resources. Public Lands Division.

8. HARRIS, S.A. and R.J.E. BROWN. 1978. Plateau Mountain: a case study of alpine permafrost in the Canadian Rocky Mountains. Pp. 385-391 in: Proc. third International Conference on Permafrost (1978), vol. 1. National Research Council of Canada, Ottawa.

9. HOWE, W.H. 1975. (ed.). The butterflies of North America. Doubleday, New York. 632 pp.

10. KARPUK, E.W. and A.G. LEVINSOHN. 1980. Physical land classification of the Livingstone-Porcupine study area. E.N.R. Report No. 127. Alberta Energy and Natural Resources, Edmonton.

11. KLASSEN, P., A.R. WESTWOOD, W.B. PRESTON, and W.B. MCKILLOP. 1989. The butterflies of Manitoba. Manitoba Museum of Man and Nature, Winnipeg. 289 pp.

12. KONDLA, N.G. 1981. Skippers and 
butterflies of a disjunct aspen parkland area in Alberta. Blue Jay 39:4-12.

13. - 1986. Skippers and butterflies of the Kootenay Plains, Alberta. Alta. Nat. 16:11-14.

14. 1992. An update on the butterflies of the Redwater sand dunes. Alta. Nat. 22:10-17.

15. 1993. The Colias alexandra complex in Alberta. Alta. Nat. 23(3):57-61.

16. KONDLA, N.G. and C.D. BIRD. 1979. Skippers and butterflies of
Kananaskis Park, Alberta. Blue Jay 37:73-85.

17. MILLER, J.Y. 1992. The common names of North American butterflies. Smithsonian Institution Press, Washington. $177 \mathrm{pp}$.

18. PINEL, H.W. 1983. Skippers and butterflies of the Indian Grove Campground area, Alberta. Blue Jay $41: 71-77$.

19. SCOTT, J.A. 1986. The butterflies of North America: a natural history and field guide. Stanford Univ. Press, Stanford. $583 \mathrm{pp}$.

Because their caterpillars eat milkweed, Monarch butterflies are considered to be distasteful, even poisonous, to birds. However, at wintering sites in Mexico, Monarchs are the main food of Black-headed Grosbeaks. Some milkweeds are less poisonous than others and the butterflies become less toxic with time. Scott. 1986. Butterflies of North America. Stanford Univ., Stanford.

On butterfly nomenclature: "The situation regarding the English names of American butterflies has been rather a mess. ... Unfortunately, scientific names can also cause confusion." Jeffrey Glassberg, Butterflying through binoculars. 